\title{
ANALYSIS OF TRACTION PROPERTIES \\ OF MASSEY FERGUSON 7475 TRACTOR ON SELECTED DEFORMABLE SURFACES
}

\author{
Krzysztof Pieczarka ${ }^{*}$, Mateusz Kierdal, Krzysztof Lejman, Zygmunt Owsiak \\ Institute of Agricultural Engineering, Wroclaw University of Environmental and Life Sciences \\ *Corresponding author: e-mail: krzysztof.pieczarka@up.wroc.pl
}

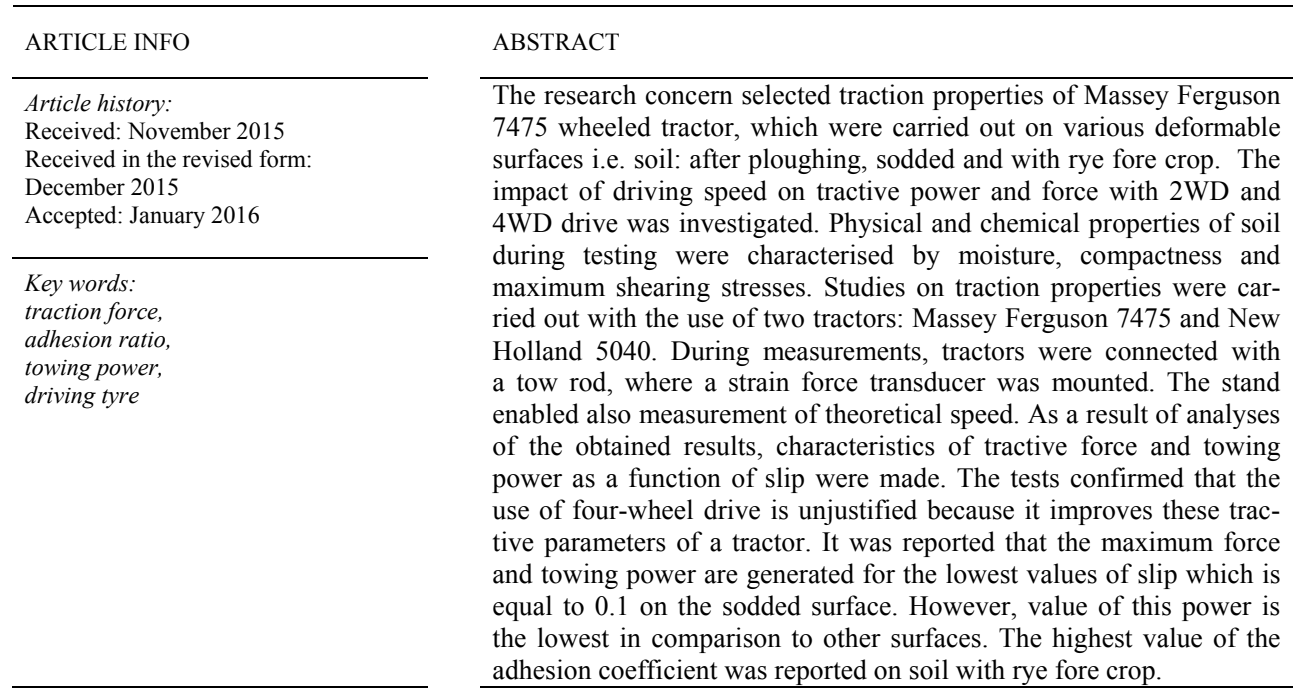

\section{Introduction}

Contemporary agriculture is characterized by introduction of newer structural technologies of agricultural machines. Along with the increase of the average area of farms in Poland, the number of tractors within $80-120 \mathrm{~kW}$ power raises. Thus, it is justified to verify the traction parameters of new structures and select appropriate drive ratios so that these machines work with the maximum efficiency and performance. It is undoubtedly related to farm tractors moving on various surfaces, which are the main driving force in agriculture and the most significant energy source (Dajniak, 1983). Producers of tractors in materials available for a user provide the maximum towing power for particular gears but as a rule they are related to the concrete surface at the slip of $15 \%$. Attestations to which tractors are subjected do not include the driving speed which is strictly related to the towing power and tractor performance (Sharma and Pandey, 2001). Varied conditions of farm tractors' operation cause that aiming to use the most advantageous traction parameters in the entire scope 
Krzysztof Pieczarka, Mateusz Kierdal, Krzysztof Lejman, Zygmunt Owsiak

of exploitation is required (Dwyer, 1984; Goering and Hansen, 2004; Wulfsohn and Way, 2009). Traction properties of the wheeled tractor result from the interaction between the wheels of a vehicle and surface, on which it moves. This influence depends on many factors such as the tractor engine, vertical loading of wheels, number of driving wheels, wheels slip, dimension of tyres (width and diameter), pressure inside tyres. Regulation or the change of the majority of these parameters is considerably limited while loading and the change of pressure inside the tyre may be regulated to a wide range and thus a tractive capacity of a tractor may be simply improved (Battiato and Diserens, 2013). The tests proved that reduction of pressure inside the tyre resulted in reduction of a negative impact of tyres on soil as well as in lower compaction of the soil profile (Abu-Hamdeh, 2003; Van et al., 2007). In the available literature there are many relations concerning the pressure inside tyres on traction properties. However, because of varied conditions during research, optimal pressure value cannot be clearly determined (Lee and Kim, 1997; Wulfsohn et al., 1998; Elwaleed et al., 2006; Šmerda and Čupera, 2010). Exploiting the same tractor on surfaces with different properties shall mean various conditions of transferring driving force. Moreover, a risk of great energy losses in the wheel-surface system occurs. First of all, it will be ecological losses (too strong damage to the surface structure and considerable economic losses (increased fuel consumption). Traction efficiency, described as a ratio of the collected energy to energy which is supplied to a wheel, which is related to losses generated by a slip and rolling resistance, is a parameter thanks to which the level of losses at transferring the drive force is determined (Zoz and Grisso, 2003).

\section{Objective, method and condition of research}

The objective of the research was to analyse the surface type impact on the selected traction properties of Massey Ferguson 7475 tractor (adhesion coefficient, force, towing power) in the aspect of forward speed changes and the drive option. Carrying out the objective of the paper was related to maintaining constant speed during measurement of towing power. It was possible due to an automatic gearbox, in which a farm tractor MF 7475 was equipped. Real driving speed was determined based on the theoretical speed and drive wheel slip.

The studies were carried out on agricultural land of Zielona Dolina Farm located in Boguszyce near Toszek, ŚląskieVoivoideship. Soil, on which investigations were carried out was characterized based on the grain distribution composition and was described as loamy sand. Measurements were carried out on ploughed soil, on soil with rye as a fore crop and on the sodded soil. Measurements were carried out at the end of March and at the beginning of April. The development stage of rye according to $\mathrm{BBCH}$ classification was described as group 2 and code 29 namely the end of tillering stage - visible maximum number of spreadings. The sodded soil included a mixture of pasture grass with the following structure: use $75 \%$, timothy grass $15 \%$, meadow fescue $10 \%$. These fields were located on two adjacent plots. Shearing stresses were determined with the use of a device for measurement of shear stresses with a Geonor probe. Measurements were carried out for three depths $(0.05 ; 0.10$ and $0.15 \mathrm{~m})$ in five iterations and the results were averaged for particular depths (Białczyk, et al., 2011). Compactness was measured with the use of Penetrologger device by Eijkelkamp. An ending with the vertical angle of $60^{\circ}$ and the area of the basis of 0.0001 
Analysis of traction properties...

$\mathrm{m}^{2}$ was used in the research. Compactness was determined in the layer of $0-0.2 \mathrm{~m}$. For measurement of humidity, a humidity sensor ThetaProbe ML $2 \mathrm{x}$ was produced by Delta- $\mathrm{T}$, which was connected to the head of the data recorder Penetrologger. Humidity for the ploughed field was $11 \%$ for soil with rye fore crop it was $23 \%$ and on the sodded soil it was $36 \%$. The highest humidity with the sodded surface was caused by a perennial plant cover which hinders water evaporation. Figure 1 presents the diagram of compactness of the investigated surface.

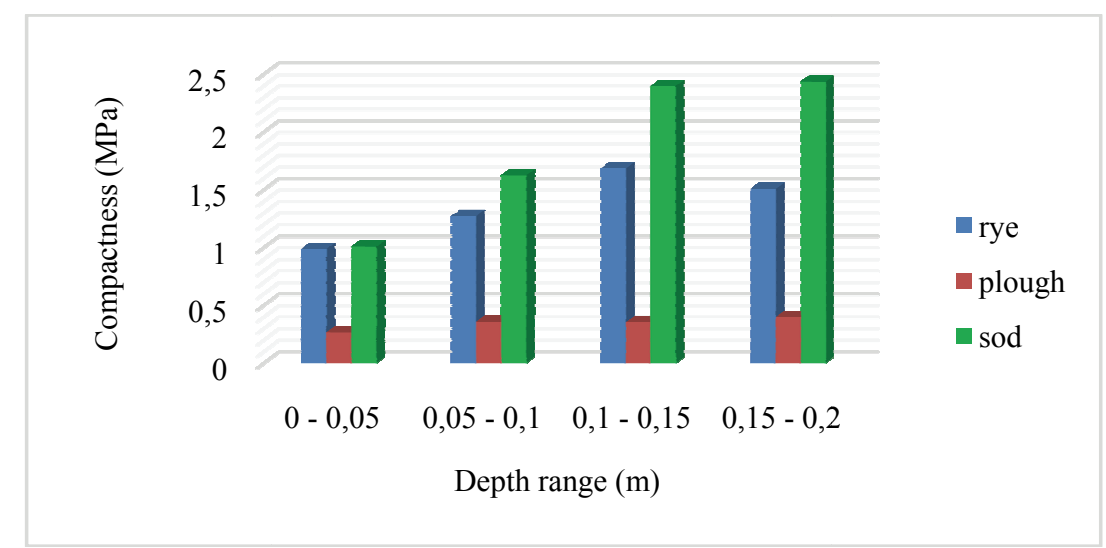

Figure 1.Compactness values as a function of depth within 0-0.2 for fields where traction properties were determined

It was reported that sodded soil is the most compact (fig. 1) and the highest values were obtained on the ploughed field. High compactness values on sod resulted from the absence of scarifying processes. Soil after ploughing had the highest compactness values of $0.4 \mathrm{MPa}$ for all depths.

Research on traction properties were carried out with the use of measurement presented in figure 2.

Tractors were connected with a tow rod inside, to which a strain force transducer was mounted. A measuring device was presented in the paper by Pieczarka (2011). A wheel was also mounted to a tow, which enabled measurement of real speed. The entire frame was mounted to an original tractor hitch. A dynamometer and a wheel which measures the speed were plugged in to the control and measurement apparatus which enables measurement and registration of sensor recommendations.

Table no. 1 presents the selected parameters of Massey Ferguson 7475 and New Holland 5040. Measurements were carried out for the option of a drive 2WD and 4WD. 


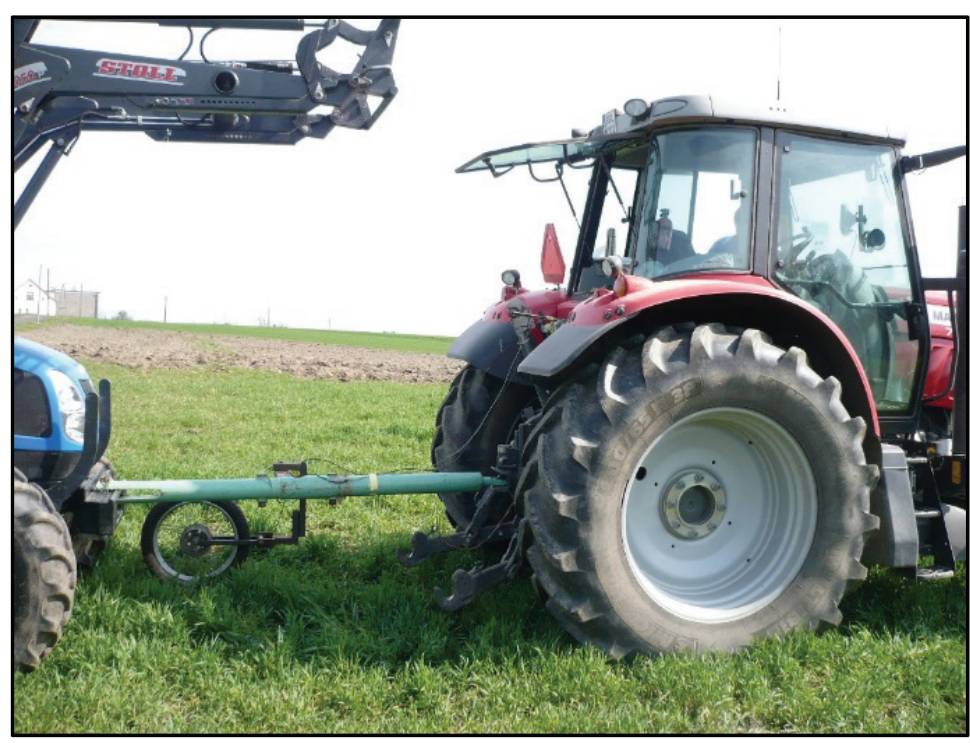

Fig. 2. Measurement stand consisting of two tractors connected with a tow rod

\section{Table 1.}

Selected tractor parameters

\begin{tabular}{lcc}
\hline Tractor & $\begin{array}{c}\text { Massey Ferguson } 7475 \\
\text { DynaVT }\end{array}$ & $\begin{array}{c}\text { New Holland } \\
5040\end{array}$ \\
\hline Engine volume $\left(\mathrm{cm}^{3}\right)$ & 6600 & 4485 \\
\hline Number of cylinders (items) & 6 & 4 \\
\hline $\begin{array}{l}\text { Nominal power according to } \\
\text { ECE-R24 }(\mathrm{kW}) \text { standard }\end{array}$ & 116.5 & 63 \\
\hline Gear & Stepless Dyna VT & Dual Command ${ }^{\mathrm{TM}} 24 / 24$ \\
\hline Weight $(\mathrm{kg})$ & 7525 & 4540 \\
\hline $\begin{array}{l}\text { Front tyre } \\
\text { Michelin MULTIBIB } \\
\text { 480-65 R28 }\end{array}$ & Firestone Performer 320-70R24 \\
\hline $\begin{array}{l}\text { Back tyre } \\
\begin{array}{l}\text { The value of pressure in } \\
\text { front tyres }(\mathrm{MPa})\end{array}\end{array}$ & $\begin{array}{c}\text { Michelin MULTIBIB 600-65R38 } \\
\text { Pressure value in back tyres } \\
\text { (MPa) }\end{array}$ & Firestone Performer 480-70R30 \\
\hline
\end{tabular}

\section{Research results and their analysis}

Figure 3 presents the towing power values as a function of slip for three various surfaces in the option of 4WD drive and speed of $1.11 \mathrm{~m} \cdot \mathrm{s}^{-1}$. 
Analysis of traction properties...

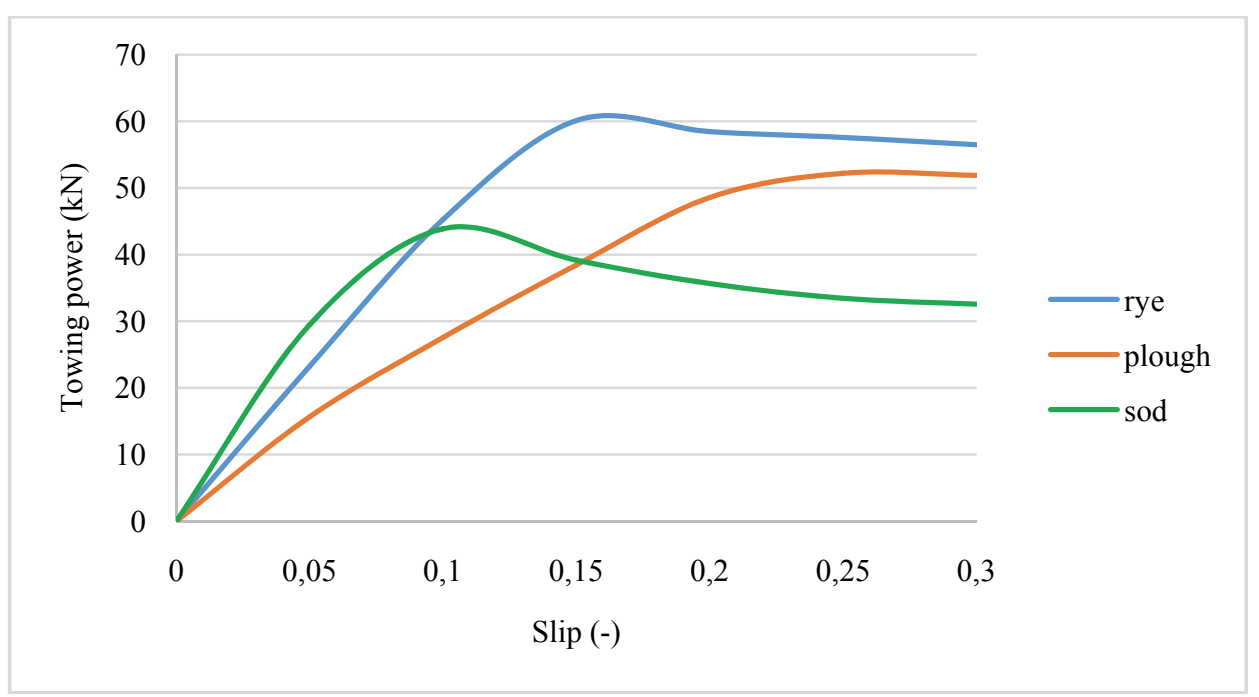

Figure 3. Course of towing power of MF 7475 as a function of slip for the investigated surfaces determined for the speed of $1.11 \mathrm{~m} \cdot \mathrm{s}^{-1}$ in the option of $4 W D$ drive

The above diagram shows that the maximum towing power for the lowest value of slip equal to 0.1 is developed on the sodded surface but the value of this power is the lowest in comparison to other surfaces. Maximum force for the sodded surface was almost $44 \mathrm{kN}$ at the slip of driving wheels 0.1 ; when comparing it to the surface - a rye field, it is a value by $37 \%$ lower. The highest power is obtained by a tractor on the surface with rye where it was ca. $60 \mathrm{kN}$ at the slip of $15 \%$. On the surface were ploughing was carried out, only at the slip of $25 \%$ the tractor achieved the maximum of its towing power equal to $52.2 \mathrm{kN}$.

In case of MF 7475 tractor there is a possibility of driving with the 2WD and 4WD drive on. Figure 4 presents maximum towing power for both drive options.

It was reported that in each analysed option, the maximum tractive force was achieved on the surface with rye. The highest towing power is achieved by MF 7475 tractors at the speed of $1.11 \mathrm{~m} \cdot \mathrm{s}^{-1}$ with the drive of $4 \mathrm{WD}$ and it was $60.12 \mathrm{kN}$ for the surface with rye. The highest power is achieved by a tractor on the sodded surface with the drive of 2WD at the speed of $2.22 \mathrm{~m} \cdot \mathrm{s}^{-1}$ and is $36.9 \mathrm{kN}$. The increase of the speed causes the decrease of the maximum towing power by $17 \%$ in case of rye and by $5 \%$ in case of ploughing. The increase of speed on sod caused the increase of the maximum towing power by $12 \%$ to the value of $50 \mathrm{kN}$. The increase of 4WD drive causes the increase of the maximum towing power by $26 \%$ at the average. The highest increase of the maximum towing power for $4 \mathrm{WD}$ drive was at the speed of $1.11 \mathrm{~m} \cdot \mathrm{s}^{-1}$ at the surface with rye and the difference was $34 \%$.

Characteristic of the towing power as a function of slip of a tractor was presented in figure 5 . 
Krzysztof Pieczarka, Mateusz Kierdal, Krzysztof Lejman, Zygmunt Owsiak

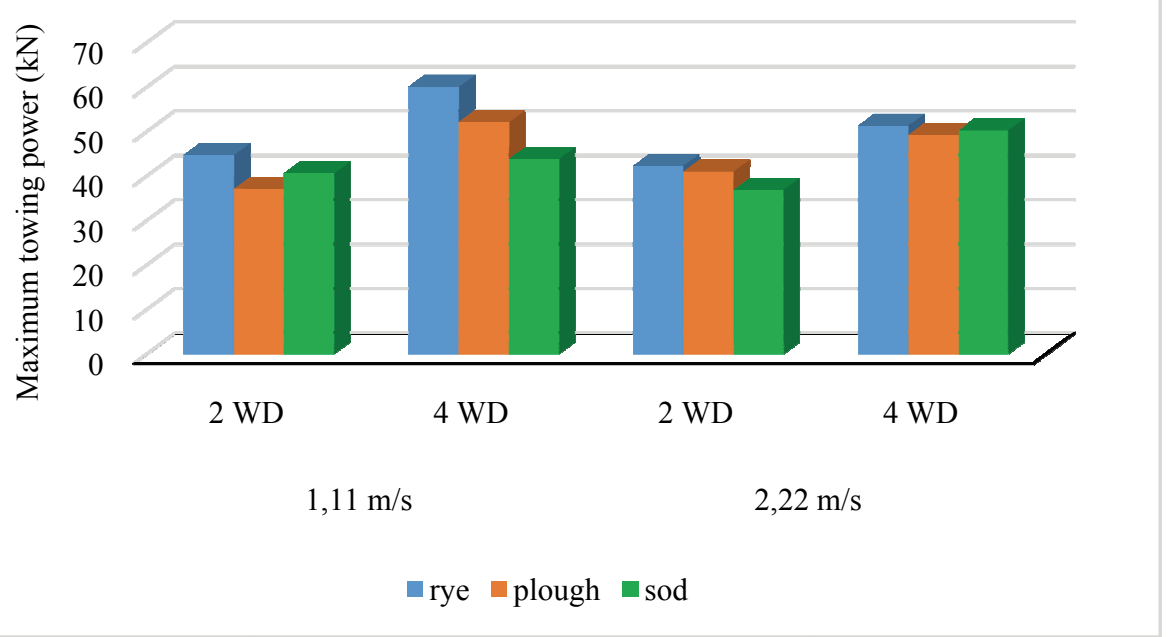

Figure 4. Values of the maximum towing power of MF 7475 tractor for the investigated surfaces determined for the accepted speeds and drive options

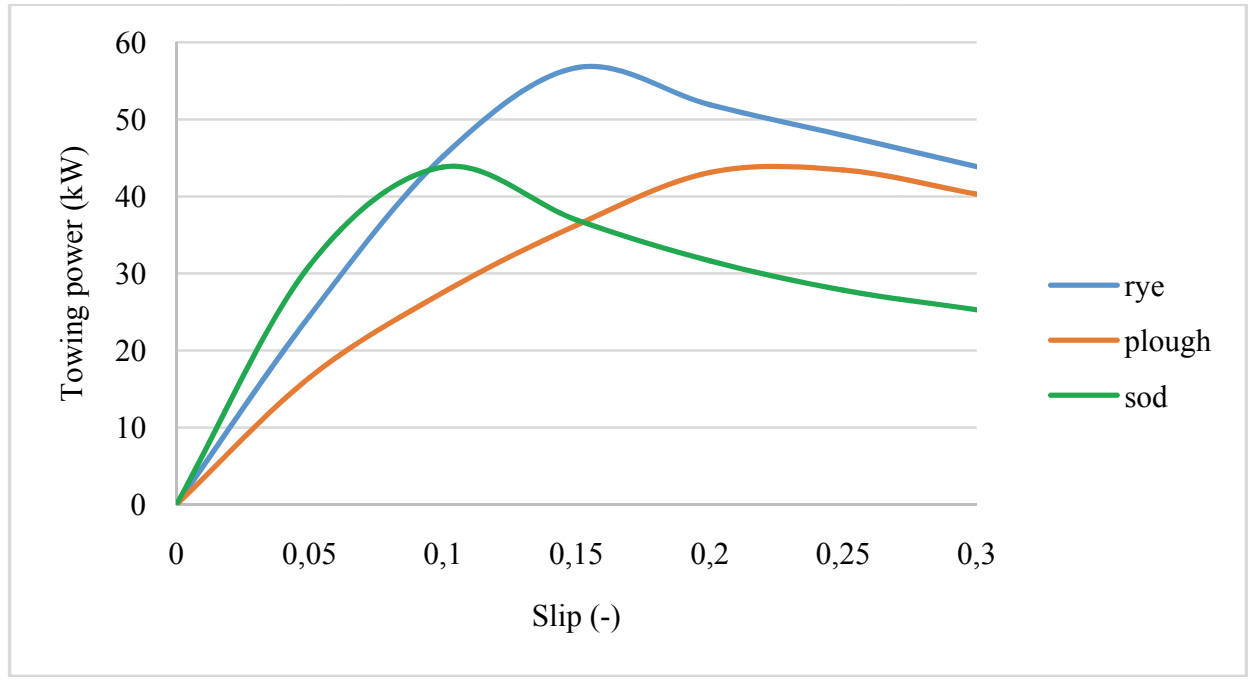

Figure 5. Courses of towing power of MF 7475 as a function of slip for the investigated surfaces determined for the speed of $1.11 \mathrm{~m} \cdot \mathrm{s}^{-1}$ in the option of $4 \mathrm{WD}$ drive

Values of the maximum towing power (fig. 5) in the option of 4WD drive for the speed of $1.11 \mathrm{~m} \cdot \mathrm{s}^{-1}$ and MF 7475 tractor were on the surface after ploughing at the slip of 0.2 on the sod, $44 \mathrm{~kW}$ for the slip 0.1 . The highest value was reported on rye as a fore crop, which was $56 \mathrm{~kW}$ at the slip of 0.15 . One should pay attention to the fact that on the sodded sur- 
Analysis of traction properties...

face, the maximum towing power is generated at a low slip equal to 0.1 which causes that sod damage is low.

Adhesion coefficient defines to what degree the tractor mass is used in specific conditions during generation of the maximum traction force. Determined values of the adhesion coefficient were presented in figure 6.

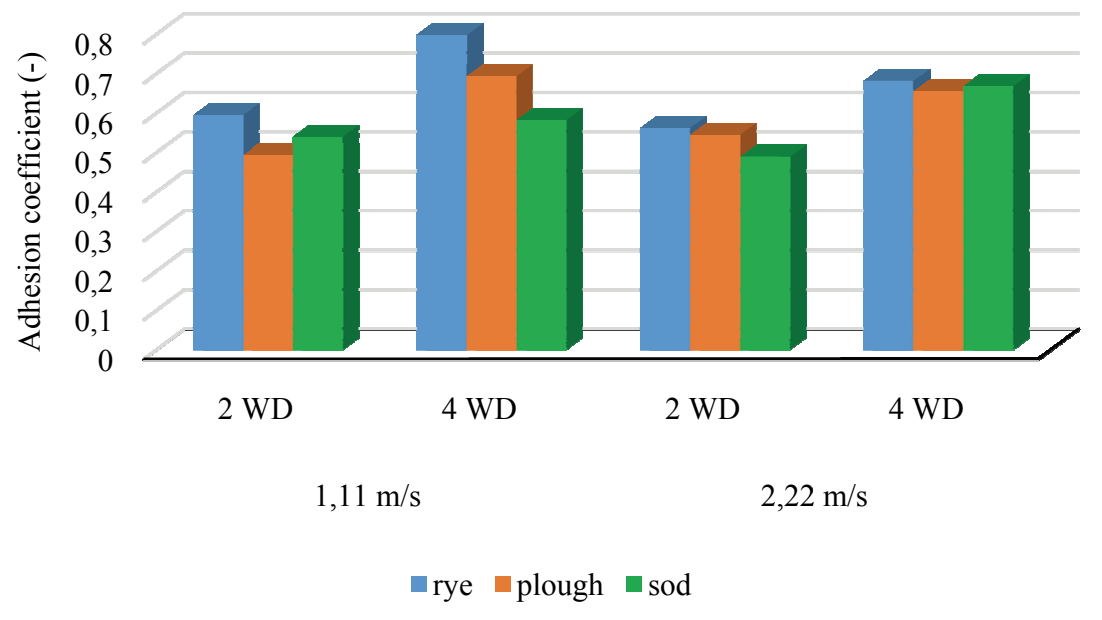

Figure 6. Values of adhesion coefficient of MF 7475 tractor for the investigated surfaces determined for the accepted speeds and drive options (author's own study)

When analysing the diagram presented in figure 6 one may unanimously state that higher values of adhesion coefficient are obtained in the variant with a drive on all wheels. The highest increase of $36 \%$ took place on the sodded surface at the speed of $2.22 \mathrm{~m} \cdot \mathrm{s}^{-1}$ and for the speed of $1.11 \mathrm{~m} \cdot \mathrm{s}^{-1}$ at the surface with rye it was $34 \%$. The lowest increase took place on sod and it was $8 \%$ for the speed of $1.11 \mathrm{~m} \cdot \mathrm{s}^{-1}$. The highest value of adhesion coefficient was obtained by MF7475 tractor on the surface with rye at the speed of $1.11 \mathrm{~m} \cdot \mathrm{s}^{-1}$ with $4 \mathrm{WD}$ drive and it was 0.8 ; the lowest value equal to 0.49 was obtained on sod with the speed of $2.22 \mathrm{~m} \cdot \mathrm{s}^{-1}$ with2WD drive.

The results of the multi-factor analysis of variance were set in table 2 .

Table 2.

Results of the multi-factor analysis of variance source: author's own study

\begin{tabular}{lccc}
\hline & Surface type & Drive option & Speed \\
\hline $\begin{array}{l}\text { Towing power } \\
\text { Adhesion }\end{array}$ & 0.4094 & $0.0015^{*}$ & 0.7699 \\
coefficient & 0.4094 & $0,0015^{*}$ & 0.7699 \\
\hline
\end{tabular}

* significantly influences the level of significance $\alpha=0.05$ 
As a result of the analysis it was found out that there was no significant impact of the type of surface and speed on the value of the towing power and adhesion coefficient. A significant impact of the drive option on the analysed dependent variables was reported.

\section{Conclusions}

1. Maximum towing power was generated at the speed of $1.11 \mathrm{~m} \cdot \mathrm{s}^{-1}$ and at the slip of $15 \%$ and it was $60 \mathrm{kN}$ on soil, which was covered with rye. The comparison of the towing power on surfaces shows that the maximum towing power on the surface with a fore crop was higher by $37 \%$ in comparison to the sodded surface and by $15 \%$ higher in comparison to the surface after ploughing.

2. The use of $4 \mathrm{WD}$ drive resulted in the rise of the adhesion coefficient on all surfaces at the average by $22 \%$. The highest increase took place in case of $4 \mathrm{WD}$ drive on the sodded surface at the driving speed of $2.22 \mathrm{~m} \cdot \mathrm{s}^{-1}$ and it was $36 \%$ which was obviously caused by strengthening of soil structure with a root system of plants.

\section{References}

Battiato, A., Diserens, E. (2013). Influence of Tyre Inflation Pressure and Wheel Load on the Traction Performance of a $65 \mathrm{~kW}$ MFWD Tractor on a Cohesive Soil. Journal of Agricultural Science, 5(8), 197-214.

Białczyk, W., Cudzik, A., Czarnecki, J., Brennensthul, M., Kaus, A. (2011).Ocena sprawności trakcyjnej opony użytkowanej na różnych podłożach rolniczych. Inżynieria Rolnicza, 8(133), 15-22.

Białczyk, W., Czarnecki, J., Cudzik, A., Brennensthul, M., Wolski, K. (2011). Ocena współpracy wybranych opon z podłożem zadarnionym. Inżynieria Rolnicza, 8(133), 23-29.

Dajniak, H. (1983). Ciagniki. Teoria ruchu i konstruowanie, WKŁ Warszawa. ISBN 83-206-0518-0.

Dwyer, M.J. (1984). Tractive performance of wheeled vehicles. Journal of Terramechanics, 21(1), 19-34.

Elwaleed, A.K., Yahya, A., Zohadie, M., Ahmad, D. (2006).Net traction ratio prediction for high-lug agricultural tyre. Journal of Terramechanics, 43, 119-139.

Goering, C.E., Hansen, A.C. (2004). Engine and Tractor Power. ASAE Publication, ISBN 1892769425.

Lee, D. R., Kim K.U. (1997): Effect of Inflation Pressure on Tractive Performance of Bias-ply Tires. Journal of Terramechanics, 34(3), 187-208.

Pieczarka, K. (2011). Analiza właściwości trakcyjnych ciągnika Fendt 820 w wybranych technologiach uprawy gleby. Inżynieria Rolnicza, 9(134), 193-199.

Sharma, A. K., Pandey, K. P. (2001). Matching tire size to weight, Speer and Power available for maximizing pul ling ability of agricultural tractors. Journal of Terramechanics, 38, 89-97.

Šmerda, T., Čupera J. (2010). Tire inflation and its influence on drawbar characteristics and performance - Energetic indicators of a tractor set. Journal of Terramechanics, 47, 395-400.

Wulfsohn, D., Upadhyaya S.K., Chancellor W.J. (1988): Tractive Characteristics of Radial Ply and Bias Ply Tires in a California Soil. Journal of Terramechanics, 25(2), 111-134.

Wulfsohn, D., Way, T.R. (2009).Factors that influence tractive performance of wheels, tracks and vehicles.Advances in Soil Dynamics vol. 3. St Joseph Michigan ASABE. 209-252.

Zoz, F., M., Grisso, R., D. (2003). Traction and Tractor Performance. ASAE Distinguished Lecture Series, Tractor Design, 27, 11-16. 
Analysis of traction properties...

\section{ANALIZA WLAŚCIWOŚCI TRAKCYJNYCH \\ CIĄGNIKA MASSEY FERGUSON 7475 NA WYBRANYCH PODLOŻACH ODKSZTALCALNYCH}

Streszczenie. Badania dotyczą wybranych właściwości trakcyjnych ciągnika kołowego Massey Ferguson 7475 , które przeprowadzono na różnych podłożach odkształcalnych tj. glebie: po orce, zadarnionej oraz z przedplonem w postaci żyta. Badano wpływ prędkości jazdy na siłę i moc uciągu z napędem 2WD i 4WD. Właściwości fizyczno-mechaniczne gleby podczas badań scharakteryzowano za pomocą: wilgotności, zwięzłości oraz maksymalnych naprężeń ścinających. Badania właściwości trakcyjnych zostały wykonane przy użyciu dwóch ciągników: Massey Ferguson 7475 i New Holland 5040. Podczas pomiarów ciągniki były połączone holem sztywnym, w którym zamontowano tensometryczny przetwornik siły. Stanowisko umożliwiało również pomiar prędkości teoretycznej. W wyniku analizy uzyskanych wyników sporządzono charakterystyki siły trakcyjnej oraz mocy uciągu w funkcji poślizgu. Badania potwierdziły, że stosowanie napędu na cztery koła jest uzasadnione, gdyż znacznie poprawia to parametry trakcyjne ciągnika. Stwierdzono, że maksymalna siła oraz moc uciągu jest generowana dla najmniejszej wartości poślizgu równej 0,1 na podłożu zadarnionym, lecz wartość tej siły jest najniższa w porównaniu z innymi podłożami. Najwyższą wartość współczynnika przyczepności odnotowano na glebie z przedplonem żyta.

Słowa kluczowe: siła trakcyjna, współczynnik przyczepności, moc uciągu, opona napędowa 